\title{
Nuclear and cytoplasmic p53 suppress cell invasion by inhibiting respiratory Complex-I activity via Bcl-2 family proteins
}

\author{
Eun Mi Kim¹,2, Jong Kuk Park ${ }^{1}$, Sang-Gu Hwang ${ }^{1}$, Wun-Jae Kim³ ${ }^{3}$ Zheng-Gang Liu ${ }^{4}$, \\ Sang Won Kang ${ }^{2}$ and Hong-Duck Um ${ }^{1}$ \\ ${ }^{1}$ Division of Radiation Cancer Biology, Korea Institute of Radiological \& Medical Sciences, Seoul, Korea \\ 2 Division of Life and Pharmaceutical Science, Ewha Woman's University Seoul, Korea \\ ${ }^{3}$ Department of Urology, College of Medicine, Chungbuk National University, Cheongju, Korea \\ ${ }^{4}$ Center for Cancer Research, National Cancer Institute, National Institutes of Health, Bethesda, MD, USA \\ Correspondence to: Hong-Duck Um, email: hdum@kcch.re.kr
}

Keywords: p53, Bcl-2 family proteins, respiratory complex-l, cell invasion

Received: June 27, $2014 \quad$ Accepted: August 05, 2014 Published: August 06, 2014

This is an open-access article distributed under the terms of the Creative Commons Attribution License, which permits unrestricted use, distribution, and reproduction in any medium, provided the original author and source are credited.

\section{ABSTRACT}

Although the p53 tumor suppressor/transcription factor often accumulates in the cytoplasm of healthy cells, limited information is available on the cytoplasmic function of p53. Here, we show that cytoplasmic p53 suppresses cell invasion by reducing mitochondrial reactive oxygen species (ROS) levels. Analysis revealed that this function is mediated by $\mathrm{Bcl}-2$ family proteins: Cytoplasmic p53 binds $\mathrm{Bcl}-\mathrm{w}$, liberating Bax, which then binds ND5, a subunit of respiratory complex-I, thereby suppressing complex-I activity and thus ROS production. The G13289A mutation of ND5, identified in cancer patients, prevents Bax/ND5 interactions and promotes ROS production and cell invasion. We also showed that $\mathrm{Bcl}-\mathrm{X}_{\mathrm{L}}$ and $\mathrm{Bak}$ can substitute for $\mathrm{Bcl}-\mathrm{w}$ and $\mathrm{Bax}$, respectively, regulating complex-I activity and supporting the cytoplasmic function of p53; nuclear p53 also suppresses complex-I activity by inducing Bax expression. Studies in animal models support the notion that p53 and $\mathrm{Bcl}-2$ family proteins exhibit these functions in vivo. This study demonstrates a link between p53 and Bcl-2 proteins as regulators of ROS production and cellular invasiveness, and reveals complex-I, especially ND5, as their functional target.

\section{INTRODUCTION}

The p53 tumor suppressor regulates numerous cellular functions, promoting cell death and suppressing cell migration and invasion [1]. Because p53 is a transcription factor, most studies of its mechanisms of action have focused on its transcriptional targets [2]. However, p53 wild-type and mutant derivatives frequently accumulate in the cytoplasm of normal and cancer cells [36], reflecting a non-transcriptional, cytoplasmic function in healthy cells. Nevertheless, information on this possibility is quite limited.

Bcl-2 family proteins are key regulators of cell death [7]. The pro-survival subfamily includes Bcl-2, Bcl- $\mathrm{X}_{\mathrm{L}}$, and $\mathrm{Bcl}-\mathrm{w}$, whereas the pro-apoptotic subfamily comprises the multidomain (Bax and Bak) and BH3-only (Bid and others) groups. In healthy cells, pro-survival members bind to multidomain pro-apoptotic members and inhibit their apoptotic activities. However, these interactions are disrupted by $\mathrm{BH} 3$-only members, which are activated upon apoptotic stimulation. Multidomain pro-apoptotic members then attack the mitochondria, inducing apoptosis.

Recent evidence suggests that $\mathrm{Bcl}-2$ proteins also regulate cellular invasiveness and thus cancer metastasis. For example, overexpression of Bcl-w, Bcl- $\mathrm{X}_{\mathrm{L}}$, or Bcl-2 in various cancer cell types increased the migratory and invasive potential of these cells [8-14], and consistently facilitated the metastasis of cancer cells in animal models $[15,16]$. Moreover, analyses of patient samples revealed the close association between up-regulation of pro-survival members and cancer metastasis $[17,18]$. While the mechanisms underlying the new functions of Bcl-2 proteins are poorly understood, it has been shown that $\mathrm{Bcl}-\mathrm{w}$ overexpression increases the levels of reactive 
oxygen species (ROS) in mitochondria, which, in turn, activates an invasion-promoting pathway that involves phosphoinositide 3-kinase (PI3K), Akt, and matrix metalloproteinase-2 (MMP-2) [8-10]. While the ability to increase ROS levels was also reported for Bcl-2 and Bcl-X $\mathrm{L}_{\mathrm{L}}[19,20]$, Bax and Bak suppress cell invasion by reducing ROS levels [10]. Analysis of this functional antagonism has revealed that Bcl-w promotes ROS production by binding and neutralizing Bax suppression of ROS [10]. Therefore, to understand the mechanism by which Bcl-2 proteins regulate ROS production and cell invasion, we must discover how Bax suppresses ROS production.

In response to apoptotic stimulation, p53 translocates from the nucleus to the mitochondria, where it interacts with $\mathrm{Bcl}-2$ proteins to promote apoptosis [21]. This supports the hypothesis that p53 constitutively accumulates in the cytoplasm of non-apoptotic, healthy cells, where it binds Bcl-2 proteins, and regulates ROS production and invasiveness. To investigate this possibility, we used cytoplasmic mutants of p53 and cells in which p53 ${ }^{\text {wt }}$ accumulates in the cytoplasm. Bcl-w and Bax were used as prototypical pro-survival and multidomain proapoptotic members, respectively. Our data showed that nuclear and cytoplasmic p53 suppress ROS production and cell invasion. These effects were mediated by Bax, which was expressed through the transcriptional activity of nuclear p53, or released from Bcl-w upon binding of cytoplasmic p53 to Bcl-w. Interestingly, Bax suppressed ROS production by binding to ND5, a subunit of respiratory complex-I, and inhibiting complex-I activity. We also provide evidence supporting the hypothesis that p53 and Bcl-2 proteins perform these functions in vivo. Therefore, the p53/Bcl-2 proteins/complex-I pathway may be considered as a new therapeutic target for cancer metastasis.

\section{RESULTS}

\section{Cytoplasmic p53 suppresses cell invasion}

p5 $3^{\mathrm{K} 305 \mathrm{~N}}$ (a lysine-to-asparagine substitution at codon 305) has been reported to accumulate in the cytoplasm [22]. To confirm this, we expressed GFP-tagged p53 ${ }^{\mathrm{wt}}$ and $\mathrm{p} 53^{\mathrm{K} 305 \mathrm{~N}}$ in p53-null H1299 lung-cancer cells. DAPI (blue) and MitoTracker-Red were used to identify nuclei and mitochondria, respectively. Confocal microscopy revealed that the green signals in GFP-p53 ${ }^{\text {wt }}$ transfectants became azure when merged with images of DAPI and MitoTracker-Red (Supplementary Figure S1). This was not observed in GFP-p53 ${ }^{\mathrm{K} 305 \mathrm{~N}}$-transfectants, where a significant portion of the green signal became yellow when the images were merged. These results support the nuclear and cytoplasmic (especially mitochondrial) localization of $\mathrm{p} 53^{\mathrm{wt}}$ and $\mathrm{p} 53^{\mathrm{K} 305 \mathrm{~N}}$, respectively, in this system.

Expression of $\mathrm{p} 53^{\mathrm{wt}}$ reduced cellular invasiveness (Figure 1A) in association with a decrease in ROS levels (Figure 1B), PI3K activity, Akt phosphorylation, and MMP-2 levels (Figure 1C). Similar results were obtained with $\mathrm{p} 53^{\mathrm{K} 305 \mathrm{~N}}$, suggesting nuclear and cytoplasmic $\mathrm{p} 53$ suppress cell invasion by blocking the ROS/PI3K/Akt/ MMP-2 pathway. Since this pathway is stimulated by Bcl-w overexpression [10], we co-expressed Bcl-w with $\mathrm{p} 53^{\mathrm{wt}}$ or $\mathrm{p} 53^{\mathrm{K} 305 \mathrm{~N}}$, both of which abolished the ability of Bcl-w to activate the invasion pathway (Figure 1A-C). Similar results were obtained when the experiments were performed with H460 lung cancer cells (Supplementary Figure S2). Therefore, both nuclear and cytoplasmic p53 appear to antagonize the invasion-promoting action of Bcl-w in multiple cell types. The introduction of $\mathrm{p} 53^{\mathrm{wt}}$, $\mathrm{p}^{5} 3^{\mathrm{K} 305 \mathrm{~N}}$, and/or Bcl-w did not significantly influence cellular viability under these (Supplementary Figure S3) and other experimental conditions [23], suggesting their effects on cell invasion do not reflect alterations in cellular viability.

\section{$\mathrm{p53}^{\mathrm{K} 305 \mathrm{~N}}$ binds $\mathrm{Bcl}-\mathrm{w}$ and disrupts its interaction with Bax}

To investigate the mechanisms underlying p53 activity, we first focused on cytoplasmic p53. The mitochondrial localization of $\mathrm{p} 53^{\mathrm{K} 305 \mathrm{~N}}$ suggests it may suppress Bcl-w-induced invasion by binding to Bcl-w. Co-immunoprecipitation assays using recombinant proteins (Figure 1D) or cell lysates (Figure 1E) indeed supported this interaction. The $\mathrm{R} 175 \mathrm{H}$ mutation (an arginine-to-histidine substitution at codon 175) in p53, which abolishes Bcl-2 and Bcl- $\mathrm{X}_{\mathrm{L}}$ binding [24], was introduced into $\mathrm{p} 53^{\mathrm{K} 305 \mathrm{~N}}\left(\mathrm{p} 53^{\mathrm{K} 305 \mathrm{~N} / \mathrm{R} 175 \mathrm{H}}\right)$. This double mutant was cytoplasmic, and a significant proportion was associated with mitochondria (Supplementary Figure S1). However, in contrast to p53 $3^{\mathrm{K} 305 \mathrm{~N}}, \mathrm{p} 53^{\mathrm{K} 305 \mathrm{~N} / \mathrm{R} 175 \mathrm{H}}$ neither interacted with Bcl-w (Figure 1D and E) nor reversed Bcl$\mathrm{w}$-induced signaling and cell invasion (Figure 1A-C). This suggests that Bcl-w binding is required for cytoplasmic p53 to antagonize the invasion-promoting action of Bcl-w. p53 ${ }^{\mathrm{K} 305 \mathrm{~N} / \mathrm{R} 175 \mathrm{H}}$ also failed to reduce the invasiveness of control cells, which do not overexpress Bcl-w (Figure 1A-C), supporting the involvement of endogenous Bcl-w in the cytoplasmic p53-mediated reduction in the basal invasiveness of H1299 cells.

Bcl-w promotes cell invasion by binding to Bax [10]; thus, binding of p53 to Bcl-w might cause dissociation of the pre-existing Bcl-w/Bax complex. This complex indeed disappeared in the presence of $\mathrm{p} 53^{\mathrm{K} 305 \mathrm{~N}}$, but not p53 ${ }^{\mathrm{K} 305 \mathrm{~N} / \mathrm{R} 175 \mathrm{H}}$ (Figure 1E and F). These findings suggest cytoplasmic p53 suppresses cell invasion by binding to Bcl-w and liberating Bax. p53 $3^{\mathrm{K} 305 \mathrm{~N}}$ also interacted with Bax (Figure 1D and E); however, in contrast to Bcl-w, 
A

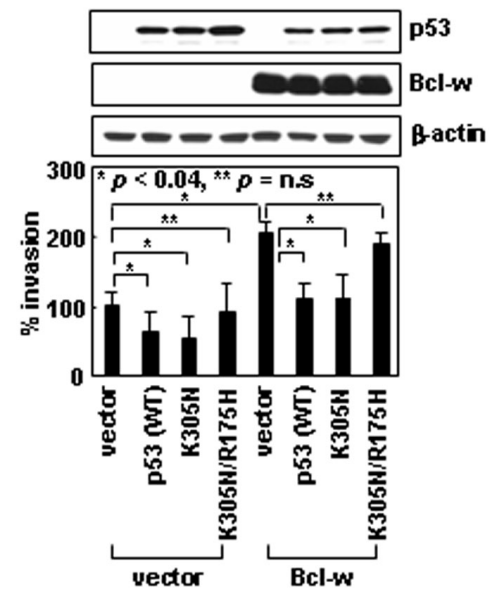

B
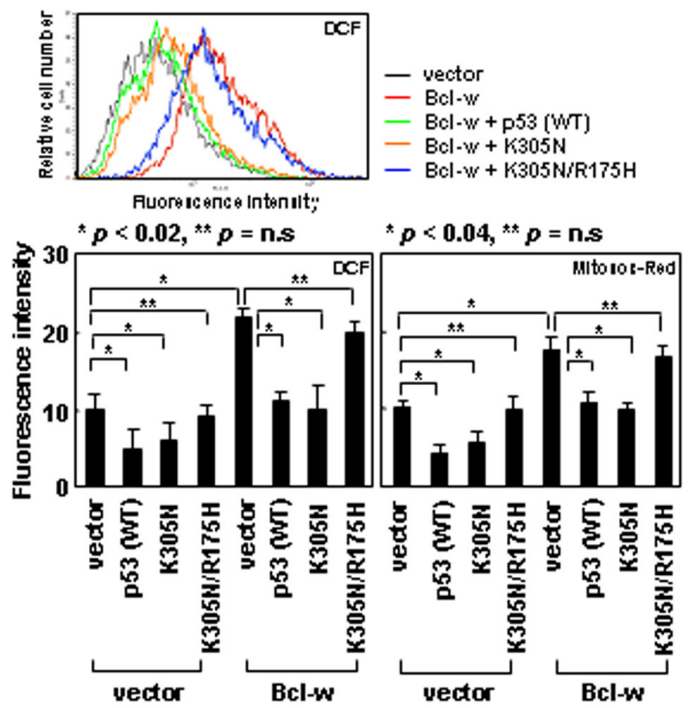

C

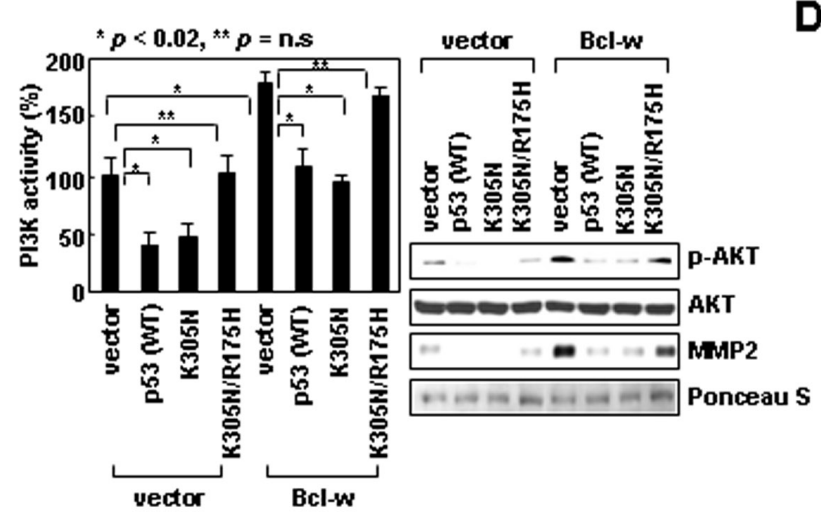

D
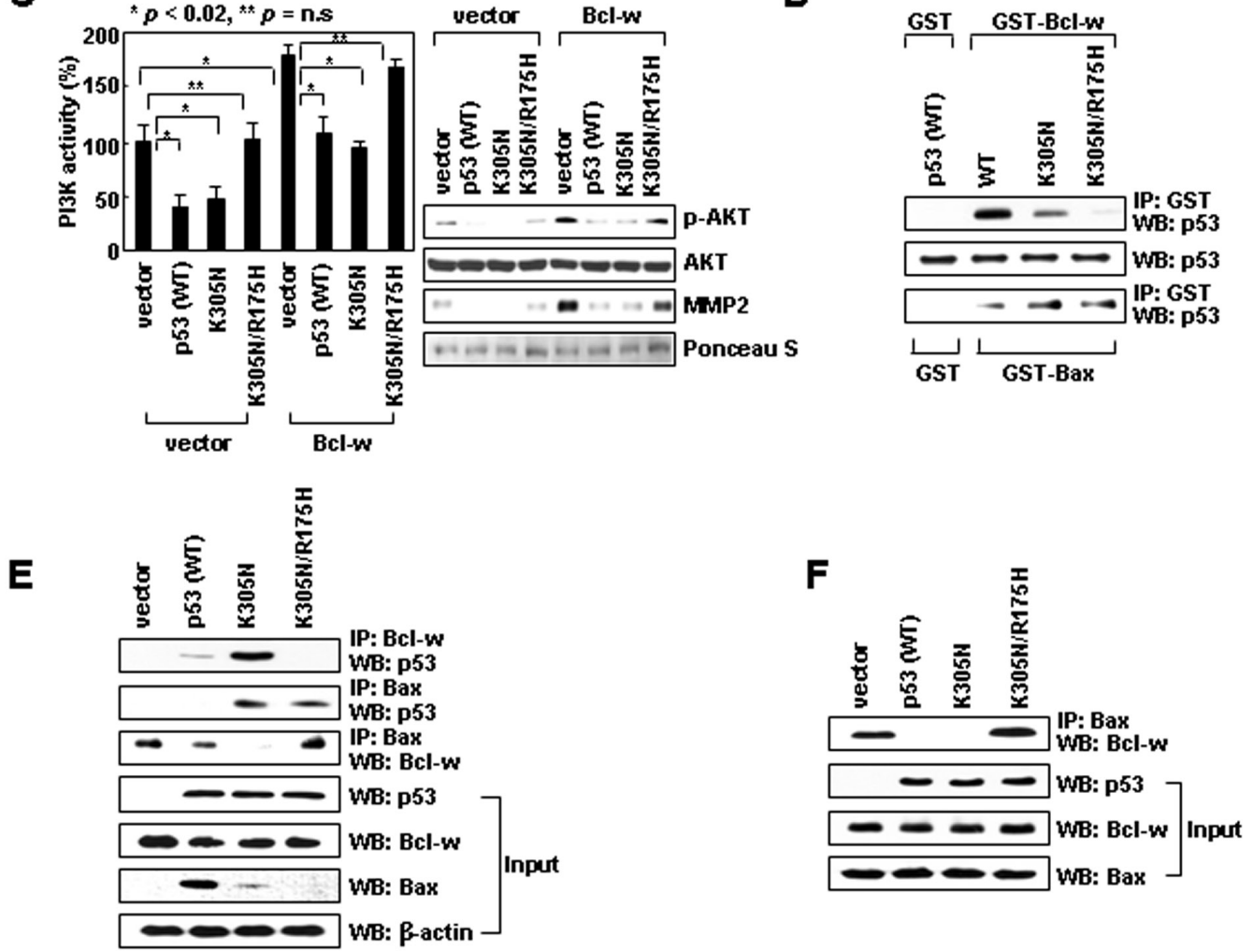

Figure 1: Cytoplasmic p53 suppresses cell invasion by binding to Bcl-w and liberating Bax from Bcl-w. (A) Empty pcDNA3 or vectors encoding Bcl-w, p53, p53 ${ }^{\mathrm{K} 305 \mathrm{~N}}$, and p53 $33^{\mathrm{K} 305 \mathrm{~N} / \mathrm{R} 175 \mathrm{H}}$ were introduced into $\mathrm{H} 1299$ cells. Gene expression was confirmed by Western blotting with $\beta$-actin as a loading control. Invasiveness was assessed on Matrigel-coated filters. ns, not significant. (B) Transfectants were analyzed for cellular and mitochondrial ROS using DCF and MitoSOX Red probes, respectively. Flow cytometry profiles of key experiments are shown on top. (C) Lysates were prepared and immunoprecipitated with an anti-PI3K antibody. PI3K activity was analyzed by competitive ELISA. Lysates were also analyzed for Akt and phospho-Akt by Western blotting. Conditioned media were prepared and analyzed for MMP-2 levels by Western blotting. Protein loading for conditioned media was verified by Ponceau S staining. (D) Wild-type and mutant p53 proteins were prepared by in vitro translation and incubated with GST, GST-Bcl-w, or GST-Bax proteins. Precipitation was carried out with glutathione-coupled Sepharose beads. Precipitates and input controls were analyzed by Western blotting with anti-p53 antibody. (E) Lysates were immunoprecipitated with anti-Bcl-w or anti-Bax antibodies. Precipitates and input controls were analyzed by Western blotting. (F) Bax and Bcl-w, together with p53 or p53 mutants, were translated in vitro. The products were verified by Western blotting (input) and immunoprecipitated with anti-Bax antibody. Levels of Bcl-w in precipitates were compared. 
Bax interacted with $\mathrm{p} 53^{\mathrm{K} 305 \mathrm{~N} / \mathrm{R} 175 \mathrm{H}}$ as well, suggesting that residue 175 of p53 is critical for binding to $\mathrm{Bcl}-\mathrm{w}$, but not Bax. Considering that only $\mathrm{p} 53^{\mathrm{K} 305 \mathrm{~N}}$, but not $\mathrm{p} 53^{\mathrm{K} 305 \mathrm{~N} / \mathrm{R} 175 \mathrm{H}}$, suppressed cell invasion despite the near-equal binding of these mutants to Bax, p53 binding to Bax does not appear to influence cellular invasiveness.

\section{Bax binds to complex-I, suppressing its activity and ROS production} by inducing mitochondrial permeability transition (MPT) [25]. However, the MPT inhibitor cyclosporine A at concentrations that inhibited the ROS production induced by lethal doses (10 Gy) of $\gamma$-rays (Supplementary Figure $\mathrm{S} 4 \mathrm{~A}$ ), failed to reduce the ROS production induced by siRNA-mediated knockdown of Bax (Supplementary Figure S4B). Thus, Bax may regulate ROS production via different mechanisms in apoptotic and healthy cells. To determine how Bax suppresses ROS production in healthy cells, we focused on the mitochondrial respiratory chain, a major source of ROS in healthy cells [26]. The
Bax promotes ROS production in apoptotic cells

chain is composed of four multimeric protein complexes (complex I-IV). Rotenone, an inhibitor of complex-I, abolished the induction of ROS accumulation and cell invasion following Bax knockdown (Figure 2A). This effect was not observed with malonate, antimycin A, or $\mathrm{KCN}$, which inhibit complexes II, III, and IV, respectively. These results suggest the specific role of complex-I in Bax knockdown-induced ROS accumulation. Bax knockdown consistently increased the activity of complex-I, but not that of other complexes (Figure 2B). Moreover, Bax was co-immunoprecipitated only with complex-I (Figure 2C). These data suggest Bax binds to complex-I and inhibits its activity, which results in a reduction in ROS production and cellular invasiveness. Bax knockdown also increased the $\Delta \Psi_{\mathrm{m}}$ and cellular ATP levels (Figure 2D), suggesting inhibition of complex-I activity by Bax results in a decrease in the $\Delta \Psi_{\mathrm{m}}$ and thus ATP production.

\section{The C-terminal tail of Bax binds to ND5}

Bax can exist in an anchored form, wherein its C-terminal tail is inserted into the outer mitochondrial
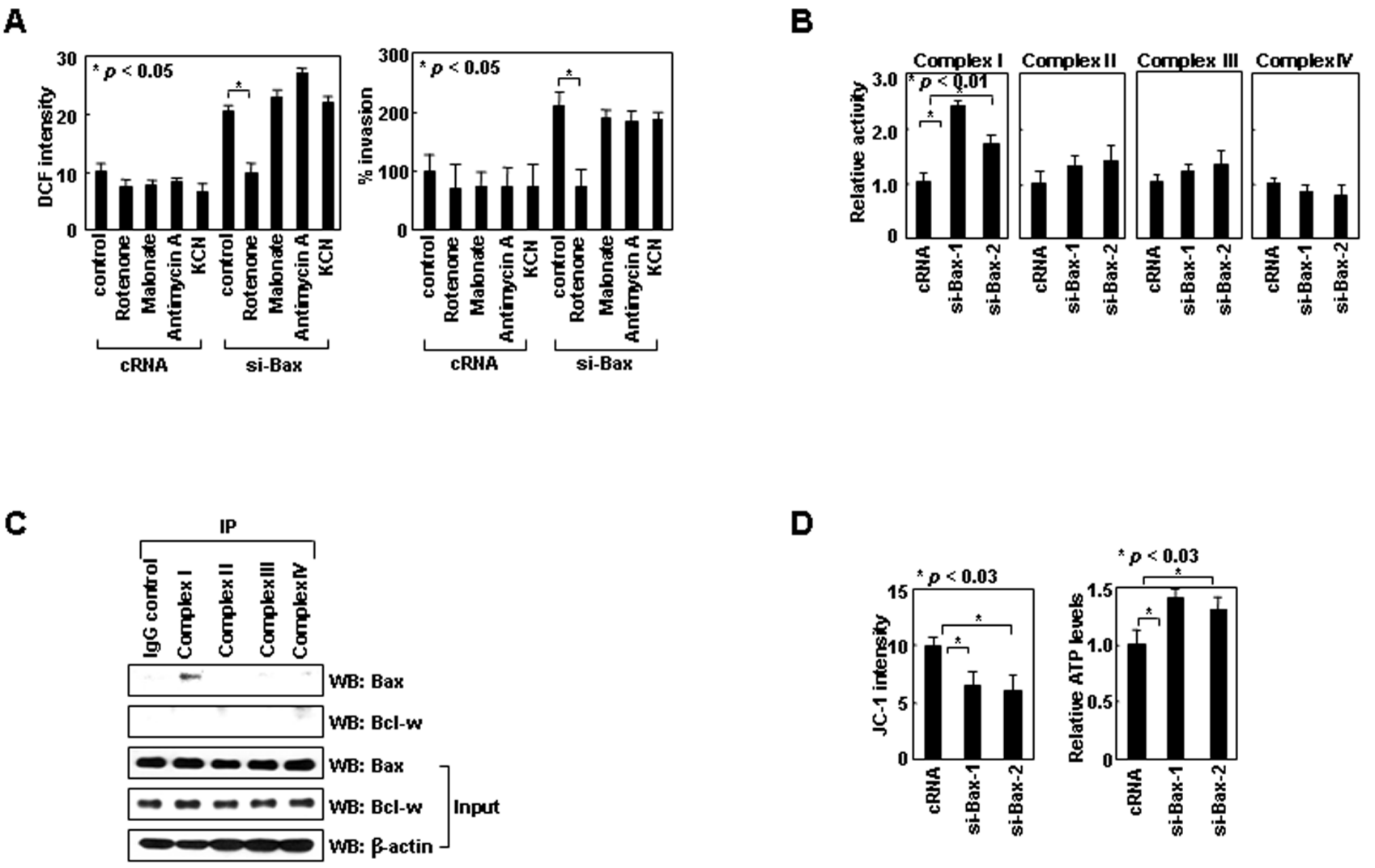

Figure 2: Bax inhibits ROS production by binding to complex-I. (A) Control or Bax siRNA was introduced into H1299 cells. After $24 \mathrm{~h}$, ROS levels and invasiveness were assessed in the presence or absence of rotenone $(1 \mu \mathrm{M})$, malonate $(5 \mathrm{mM})$, antimycin $\mathrm{A}(10$ $\mu \mathrm{M})$, or $\mathrm{KCN}(500 \mu \mathrm{M})$. (B) Cells treated with control or two sets of Bax siRNA were lysed and analyzed for complex I-IV activities. (C) H1299 cell lysates were immunoprecipitated using antibodies against each complex. Levels of Bax and Bcl-w in precipitates and input controls were compared. A control IgG, used as a negative control, is shown in the first lane. (D) Cells treated with siRNA were loaded with JC-1 and analyzed for $\Delta \Psi_{\mathrm{m}}$ by flow cytometry. Alternatively, cells were lysed for ATP assays. 
membrane in unstressed cells [27-30]. This topology allows the four C-terminal residues of $\mathrm{Bax}(\mathrm{KKMG})$ to protrude into the intermembrane space. Human complex-I consists of 45 subunits that form two arms; a membrane arm, which resides in the inner mitochondrial membrane, and a matrix arm, which protrudes into the mitochondrial matrix [31]. Some of the subunits in the membrane arm are exposed to the intermembrane space; thus, the $\mathrm{C}$-terminal four residues of Bax might be involved in the interaction of Bax with complex-I. To investigate this possibility, we deleted these residues (Bax $\Delta \mathrm{C} 4)$ and expressed Bax and $\mathrm{Bax} \Delta \mathrm{C} 4$ using an inducible vector in LoVo colon-cancer cells, which do not express endogenous Bax [32]. This treatment did not significantly influence viability (Supplementary Figure S5). Whereas expression of Bax resulted in efficient formation of a complex between Bax and complex-I, complex formation was diminished in BaxC4-transfectants (Figure 3A). This suggests that the $\mathrm{C}$-terminal four residues support binding of Bax to complex-I. Moreover, cellular ROS levels and invasiveness were reduced by the expression of Bax, but not $\operatorname{Bax} \Delta \mathrm{C} 4$, supporting the requirement of Bax/complex-I interaction for the ROS-suppressing function of Bax.

To determine which part of complex-I interacts with Bax, we analyzed three subunits in the membrane arm (ND1, ND2, ND5) and two subunits in the matrix arm (NDUFS1, NDUFV2) and found that Bax coimmunoprecipitated only with ND5 (Figure 3B and C). However, ND5 did not co-immunoprecipitate with $\operatorname{Bax} \Delta \mathrm{C} 4$ (Figure 3C), suggesting that Bax specifically binds to ND5 through its C-terminal tail.

\section{A natural mutation of ND5 prevents binding to Bax}

Interestingly, complex-I, especially ND5, is a frequent target for natural mutation in lung cancer patients
A

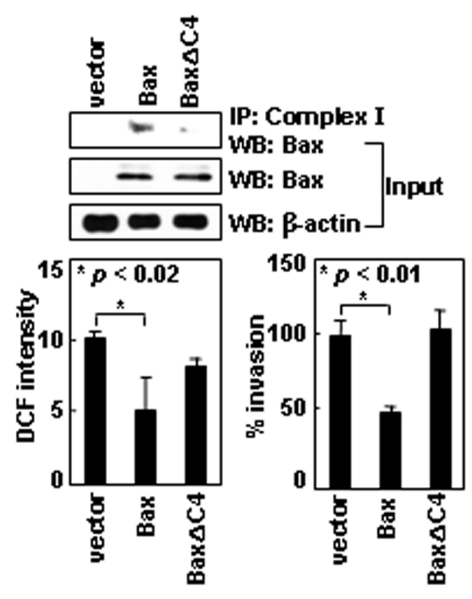

B

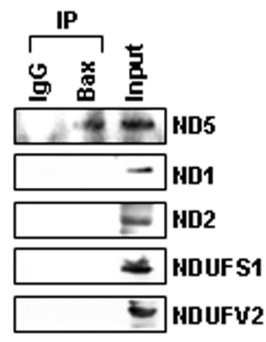

$\mathbf{E}$

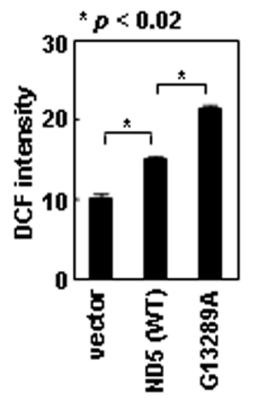

C

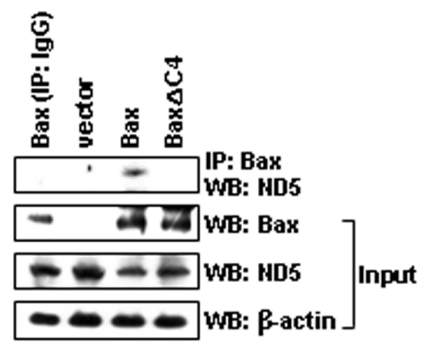

Figure 3: Bax binds to ND5 via its C-terminal tail. (A) LoVo cells transfected with pTRE, pTRE-Bax, or pTRE-Bax $\Delta C 4$ vectors were treated with tetracycline $(1 \mu \mathrm{g} / \mathrm{mL})$ for $16 \mathrm{~h}$ to induce gene expression. Lysates were prepared and immunoprecipitated with anticomplex-I antibody. Precipitates and inputs were analyzed by Western blotting with anti-Bax antibody. Transfectants were also analyzed for ROS levels and invasiveness. (B) H1299 lysates were immunoprecipitated with anti-Bax or control IgG. Levels of ND5, ND1, ND2, NDUFS1, and NDUFV2 in precipitates and inputs were assessed by Western blotting. (C) LoVo cell transfectants were lysed and immunoprecipitated with anti-Bax or control IgG. Levels of ND5 were compared. (D) H1299 cells transfected with empty pCMV/myc/ mito vectors or vectors encoding ND5 and ND5 ${ }^{\mathrm{G} 13289 \mathrm{~A}}$ were lysed. Immunoprecipitation and Western blotting were performed. (E) The transfectants were assayed for ROS and invasiveness. 
[33]. The G13289A mutation of ND5 is one such example. In contrast to ND5, ND5 ${ }^{\mathrm{G} 13289 \mathrm{~A}}$ failed to bind to Bax (Figure 3D). Moreover, while the overexpression of ND5 resulted in an increase in ROS production and cellular invasiveness, ND5 ${ }^{\mathrm{G} 13289 \mathrm{~A}}$ was superior to ND5 in inducing such effects (Figure 3E). These results support the notion that ND5 promotes ROS production and cell invasion, and this activity is suppressed by binding to Bax.

\section{Bcl-w activates complex-I by inhibiting Bax/ complex-I interactions}

Like Bax siRNA, Bcl-w-induced ROS accumulation and cell invasion were also prevented specifically by rotenone (Figure 4A). Bcl-w overexpression consistently elevated the activity of complex-I, but not that of complexes II-IV (Figure 4B), and increased $\Delta \Psi_{\mathrm{m}}$ and ATP levels (Figure 4C). Therefore, Bcl-w appears to activate complex-I, resulting in increases in $\Delta \Psi_{\mathrm{m}}$ and ATP levels as well as ROS production and cellular invasiveness. However, in contrast to Bax, Bcl-w did not efficiently bind to any respiratory complexes (Figure 2C), raising the possibility that Bcl-w activates complex-I by binding to
Bax. Indeed, Bcl-w failed to increase complex-I activity, $\Delta_{\mathrm{m}}$, and ATP levels when its interaction with Bax was prevented by introducing the G94A mutation into Bcl-w [10] (Figure 4B and C). Moreover, Bax/complex-I and Bax/ND5 interactions were dramatically reduced by overexpression of Bcl-w, but not Bcl-w ${ }^{\mathrm{G} 94 \mathrm{~A}}$ (Figure 4D), suggesting that Bcl-w prevents Bax/complex-I (ND5) interactions by binding to Bax. Thus, it appears that Bcl-w activates complex-I by binding to Bax and promoting the release of Bax from complex-I.

\section{Cytoplasmic p53 suppresses complex-I activity by promoting Bax/complex-I interactions}

These findings suggest cytoplasmic p53 also regulates complex-I activity. $\mathrm{p} 53^{\mathrm{K} 305 \mathrm{~N}}$ expression indeed reduced complex-I activity, and thus $\Delta \Psi_{\mathrm{m}}$ and ATP levels as well (Figure 4E). In addition, $\mathrm{p} 53^{\mathrm{K} 305 \mathrm{~N}}$ expression promoted Bax/complex-I and Bax/ND5 interactions (Figure 4F), suggesting cytoplasmic p53 suppresses complex-I activity by facilitating Bax/complex-I interactions. This activity may be mediated by binding to Bcl-w, which dissociates the Bcl-w/Bax complex. Indeed,
A
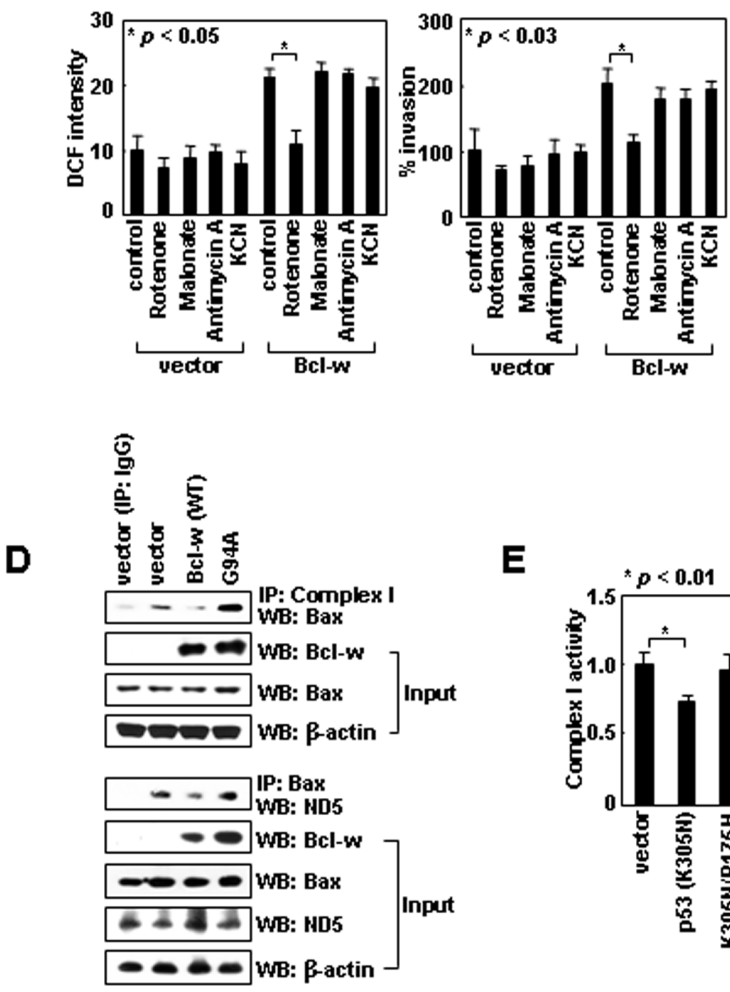

B

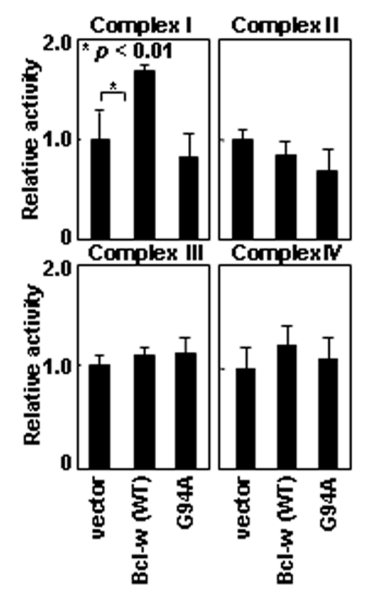

E

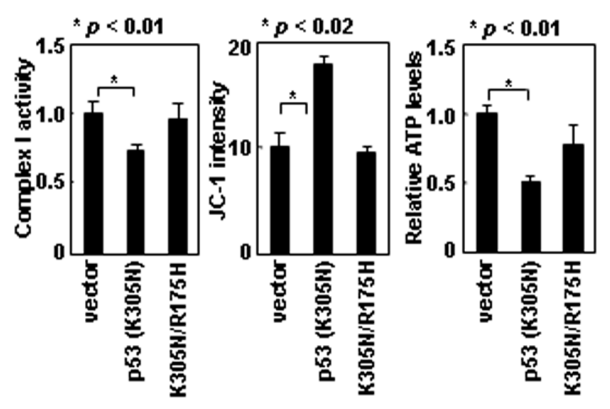

C
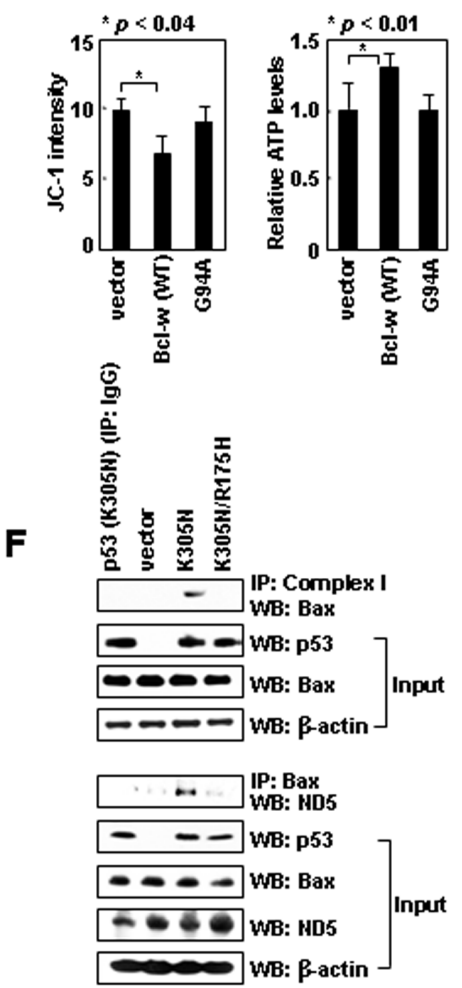

Figure 4: Bcl-w and cytoplasmic p53 regulate the interaction of Bax with complex-I. (A) Control and Bcl-w transfectants of H1299 cells were analyzed for ROS levels and invasiveness in the presence or absence of rotenone $(1 \mu \mathrm{M})$, malonate $(5 \mathrm{mM})$, antimycin A $(10 \mu \mathrm{M})$, or $\mathrm{KCN}(500 \mu \mathrm{M})$. (B) Control, Bcl-w, and Bcl-w ${ }^{\mathrm{G} 94 \mathrm{~A}}$ transfectants were lysed and complex I-IV activities were compared. (C) Transfectants were analyzed for $\Delta \Psi_{\mathrm{m}}$ and ATP. (D) Cells were lysed, immunoprecipitated, and analyzed by Western blotting. (E) Control, p53 ${ }^{\mathrm{K} 305 \mathrm{~N}}$, and $\mathrm{p} 53^{\mathrm{K} 305 \mathrm{~N} / \mathrm{R} 175 \mathrm{H}}$ transfectants were analyzed for complex-I activity, $\Delta \Psi_{\mathrm{m}}$, and ATP. (F) The transfectants were lysed, immunoprecipitated, and analyzed by Western blotting. 
$\mathrm{p} 53^{\mathrm{K} 305 \mathrm{~N} / \mathrm{R} 175 \mathrm{H}}$ failed to mimic the actions of $\mathrm{p} 53^{\mathrm{K} 305 \mathrm{~N}}$ (Figure $4 \mathrm{E}$ and $\mathrm{F}$ ), supporting the requirement of $\mathrm{p} 53 / \mathrm{Bcl}-\mathrm{w}$ interaction for Bax/complex-I interaction and inhibition of complex-I activity.

\section{Cytoplasmic p53 $^{\mathrm{wt}}$ mimics $5^{\mathrm{K} 305 \mathrm{~N}}$}

To validate the functions of cytoplasmic p53, we used human IMR-32 neuroblastoma cells in which p53 ${ }^{\mathrm{wt}}$ accumulates in the cytoplasm for unknown reasons [34]. Knockdown of p53 in these cells by siRNA increased ROS levels and cellular invasiveness (Figure 5A), suggesting cytoplasmic $\mathrm{p} 53^{\mathrm{wt}}$ suppresses ROS-dependent invasion in these cells. p53 knockdown greatly increased Bcl-w/ Bax complex levels without significant influence on Bcl-w or Bax levels (Figure 5B). This was accompanied by a decrease in Bax binding to complex-I and ND5 (Figure $5 B$ ), as well as increases in complex-I activity, $\Delta \Psi_{\mathrm{m}}$, and ATP levels (Figure 5C). These results suggest cytoplasmic p5 $3^{\mathrm{wt}}$ facilitates the dissociation of Bax from Bcl-w, resulting in the association of Bax with complex-I (ND5) and thus a reduction in complex-I activity, $\Delta \Psi_{\mathrm{m}}$, and ATP levels. Moreover, p53 knockdown with concurrent siRNA- mediated knockdown of Bcl-w or Bax failed to alter cellular invasiveness (Figure 5D), suggesting cytoplasmic $\mathrm{p} 53^{\mathrm{wt}}$ suppresses cell invasion in a manner dependent upon Bcl-w and Bax. Overall, the characteristics of cytoplasmic $\mathrm{p} 53^{\mathrm{wt}}$ are similar to those of $\mathrm{p} 53^{\mathrm{K} 305 \mathrm{~N}}$, suggesting both suppress cell invasion via the same mechanism.

\section{$B c l-X_{L}$ and Bak can substitute for Bcl-w and Bax, respectively, in support of the cytoplasmic functions of p53}

The role of Bcl-w and Bax in the cytoplasmic function of p53 may extend to other pro-survival and multidomain pro-apoptotic members. Like Bcl-w, Bcl$X_{L}$ overexpression increased complex-I activity, $\Delta \Psi_{m}$, and ATP levels (Figure 6A). Moreover, Bcl- $\mathrm{X}_{\mathrm{L}}$ bound to $\mathrm{p} 53^{\mathrm{K} 305 \mathrm{~N}}$, but not $\mathrm{p} 53^{\mathrm{K} 305 \mathrm{~N} / \mathrm{R} 175 \mathrm{H}}$, and only $\mathrm{p} 53^{\mathrm{K} 305 \mathrm{~N}}$ antagonized the ability of Bcl- $\mathrm{X}_{\mathrm{L}}$ to interact with Bax (Figure 6B) and increase ROS levels and cellular invasiveness (Figure 6C). These results suggest binding of cytoplasmic p53 to $\mathrm{Bcl}-\mathrm{X}_{\mathrm{L}}$ promotes the release of Bax from $B c l-X_{L}$, which then results in suppression of complex-I activity, ROS production, and cellular
A

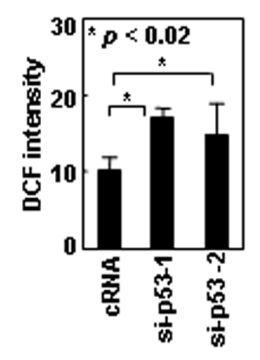

B

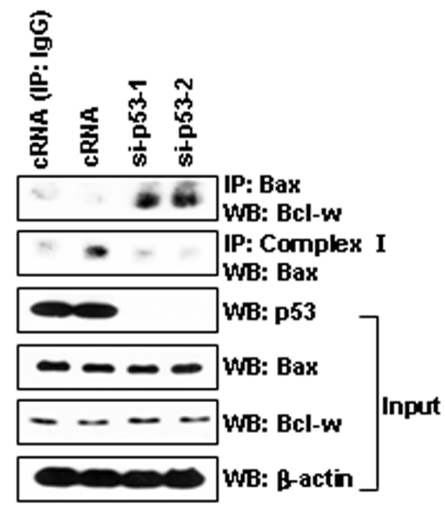

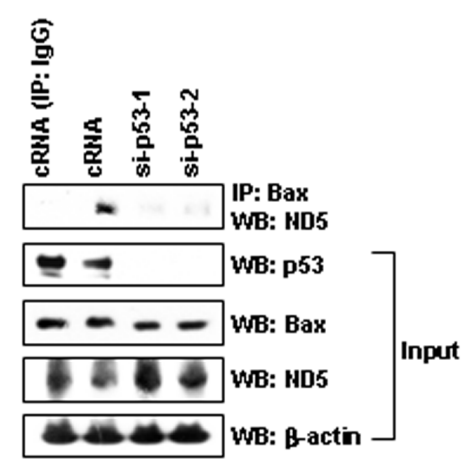

C

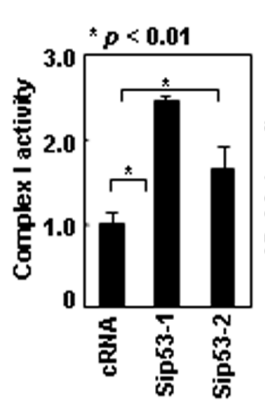

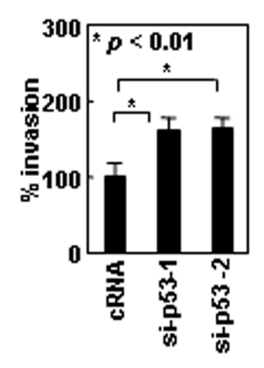
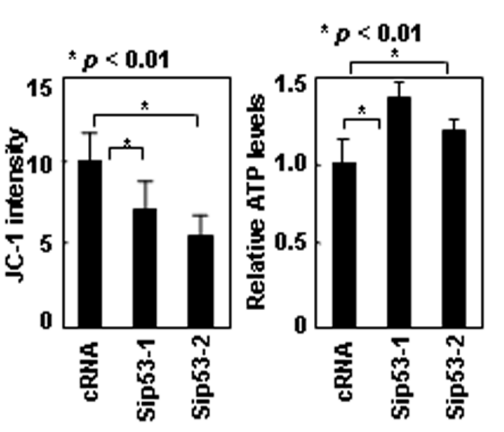

D

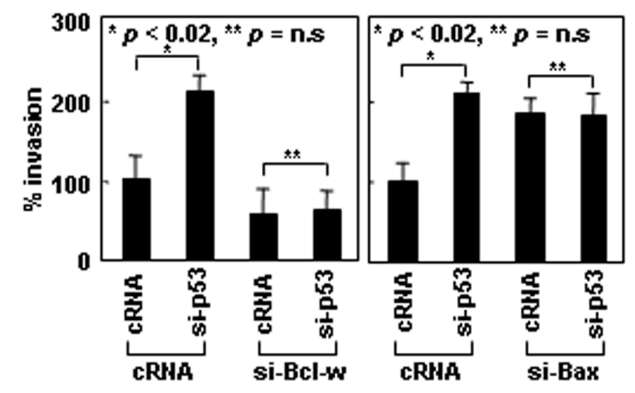

Figure 5: Cytoplasmic p53 ${ }^{\mathrm{wt}}$ mimics $\mathbf{p 5 3}{ }^{\mathrm{K} 305 \mathrm{~N}}$. (A) IMR-32 cells treated with control or p53 siRNA were analyzed for ROS and invasiveness. (B) Lysates were immunoprecipitated with anti-Bax or anti-complex-I antibodies. Precipitates and input controls were analyzed by Western blotting. (C) Treated cells were analyzed for complex-I activity, $\Delta \Psi_{\mathrm{m}}$, and ATP. (D) IMR-32 cells were treated with control, p53, Bcl-w, and Bax siRNAs for $24 \mathrm{~h}$ and assayed for invasiveness. 
invasiveness. Therefore, $\mathrm{Bcl}-\mathrm{X}_{\mathrm{L}}$ and $\mathrm{Bcl}-\mathrm{w}$ appear to play common roles in the invasion-suppressing action of cytoplasmic p53.

To determine whether Bak could mimic Bax in this system, we used LoVo cells, in which Bak-knockdown increased ROS levels and cellular invasiveness [10]. These effects were accompanied by increases in complex-I activity, $\Delta \Psi_{\mathrm{m}}$, and ATP (Figure 6D). Moreover, Bak interacted with ND5 in a manner that depended on its C-terminal 4 residues (FFKS) (Figure 6E). These results suggest that Bak, like Bax, binds via its C-terminal tail to ND5, and suppresses complex-I activity, ROS production, and cellular invasiveness. Moreover, whereas the introduction of $\mathrm{p} 53^{\mathrm{K} 305 \mathrm{~N}}$ reduced the invasiveness of control LoVo cells, this effect was not observed in Bakknockdown LoVo cells (Figure 6F), suggesting that p53 ${ }^{\mathrm{K} 305 \mathrm{~N}}$ suppresses LoVo cell invasion in a Bak-dependent manner. The introduction of $\mathrm{p} 53^{\mathrm{K} 305 \mathrm{~N}}$ indeed facilitated dissociation of Bak from Bcl-w, and enhanced the binding of Bak to complex-I (Figure 6G). These effects were not observed with $\mathrm{p} 53^{\mathrm{K} 305 \mathrm{~N} / \mathrm{R} 175 \mathrm{H}}$, suggesting cytoplasmic $\mathrm{p} 53$ binds to Bcl-w to liberate Bak. The properties of Bak are similar to those of Bax, suggesting both suppress cell invasion via a common mechanism.

\section{Nuclear p53 suppresses invasion by inducing Bax expression}

To investigate the mechanism whereby nuclear p53 suppresses invasion, we focused on Bax, a transcriptional target of p53. Expression of p53 in H1299 cells indeed elevated the levels of Bax, but not Bak, Bcl-w, or Bcl$\mathrm{X}_{\mathrm{L}}$ (Figure 7A). The Bax induction was not observed by expressing $\mathrm{p} 53^{\mathrm{R} 175 \mathrm{H}}$, which localized to the nucleus (Supplementary Figure S1), but lacked DNA-binding ability [35]. p53 ${ }^{\mathrm{R} 175 \mathrm{H}}$ also failed to suppress invasion (Figure 7B), suggesting that the transcriptional activity of nuclear p53 and subsequent Bax accumulation are required for this activity. The requirement of Bax was indeed supported by data showing that p53 failed to reduce ROS and invasiveness when Bax accumulation was
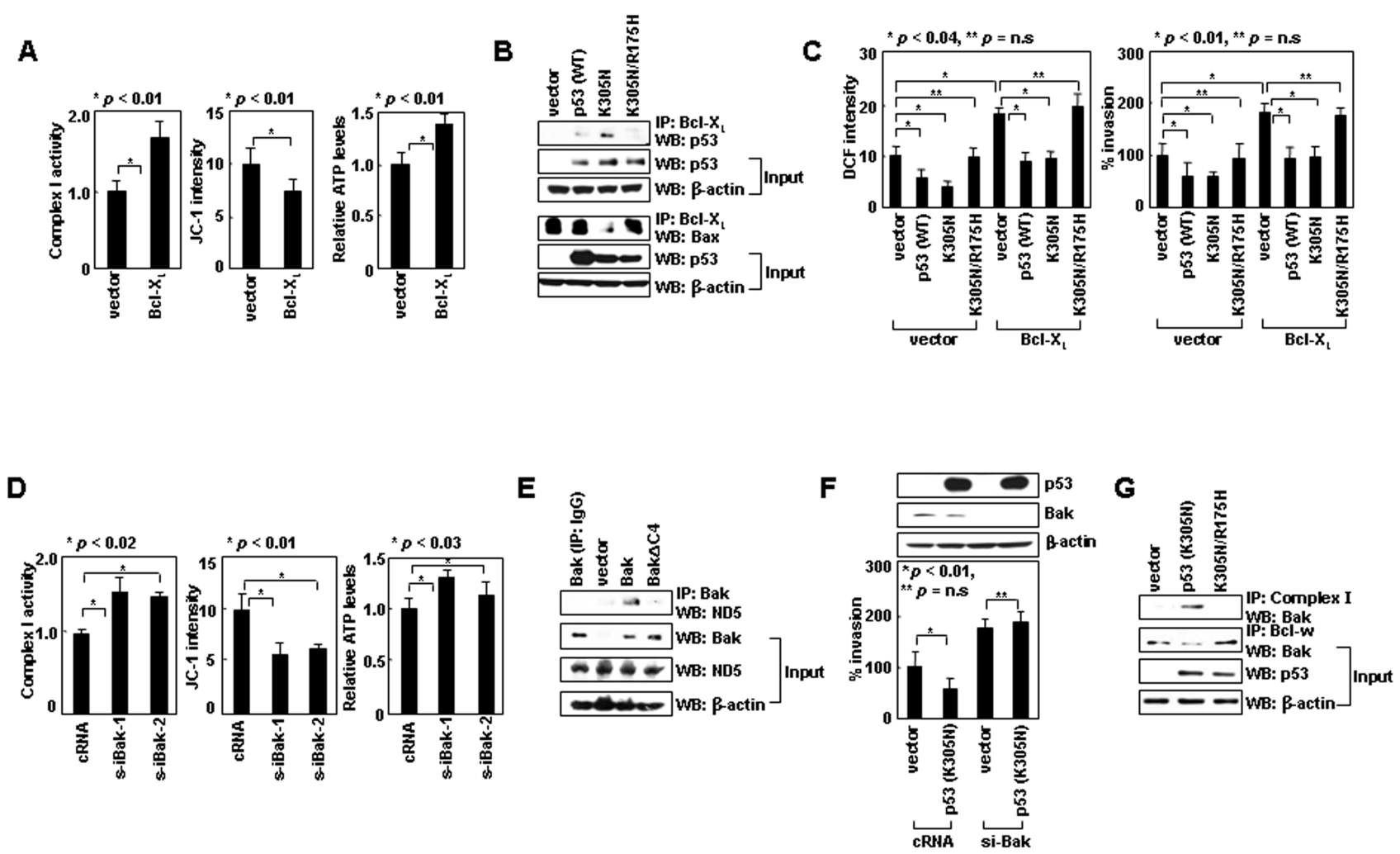

Figure 6: Bcl- $\mathrm{X}_{\mathrm{L}}$ and Bak can substitute for Bcl-w and Bax, respectively, in regulating complex-I. (A) Control and Bcl$\mathrm{X}_{\mathrm{L}}$ transfectants of $\mathrm{H} 1299$ were analyzed for complex I activity, $\Delta \Psi_{\mathrm{m}}$, and ATP. (B) Control, p53, p53 ${ }^{\mathrm{K} 305 \mathrm{~N}}$, and p53 ${ }^{\mathrm{K} 305 \mathrm{~N} / \mathrm{R} 175 \mathrm{H}}$ transfectants of $\mathrm{H} 1299$ cells were lysed and immunoprecipitated with anti-Bcl- $\mathrm{X}_{\mathrm{L}}$ antibody. Precipitates were then analyzed by Western blotting with anti-p53 and anti-Bax antibodies. (C) Cells were analyzed for ROS and invasiveness. (D) LoVo cells were treated with control or Bak siRNA for $24 \mathrm{~h}$ and analyzed for complex I activity, $\Delta \Psi_{\mathrm{m}}$, and ATP. (E) LoVo cells were transfected with empty pTRE vector or pTRE expression vectors for Bak or Bak $\Delta C 4$. Transfectants were treated with tetracycline $(1 \mu \mathrm{g} / \mathrm{mL})$ for $24 \mathrm{~h}$ to induce gene expression. Lysates were prepared and immunoprecipitated with anti-Bak antibody. The levels of ND5 were analyzed by Western blotting. (F) Control or Bak siRNA as well as pcDNA3 or pcDNA3/p53 $3^{\mathrm{K} 305 \mathrm{~N}}$ were introduced into LoVo cells in the indicated combinations and invasiveness was compared. (G) Control, p53 $3^{\mathrm{K} 305 \mathrm{~N}}$, and $\mathrm{p} 53^{\mathrm{K} 305 \mathrm{~N} / \mathrm{R} 175 \mathrm{H}}$ transfectants of LoVo cells were lysed and immunoprecipitated with anti-complex-I or anti-Bcl-w antibodies. Bak levels were assessed by Western blotting. 
prevented by siRNA (Figure 7C). In contrast, nuclear p53 efficiently reduced ROS levels and cellular invasiveness even when Bcl-w was knocked down. This suggests that nuclear p53 suppresses invasion in a manner independent of Bcl-w, which is consistent with the notion that Bax acts downstream of Bcl-w. p53 expression also facilitated Bax/complex-I interactions (Figure 7D), and thus reduced complex-I activity, $\Delta \Psi_{\mathrm{m}}$, and ATP levels (Figure 7E). These effects were not observed with $\mathrm{p} 53^{\mathrm{R} 175 \mathrm{H}}$, indicating a requirement for $\mathrm{p} 53$ transcriptional activity. These data suggest nuclear p53 suppresses invasion by inducing Bax, which then binds to complex-I and inhibits ROS production.

\section{The $\mathbf{p 5 3 / B c l - w / B a x ~ s y s t e m ~ r e g u l a t e s ~ c a n c e r ~ c e l l ~}$ intravasation}

To investigate whether the $\mathrm{p} 53 / \mathrm{Bcl}-\mathrm{w} / \mathrm{Bax}$ system modulates cellular behavior in vivo, we utilized a mouse model to compare the intravasation potential of cancer cells, a property that depends on their invasive activity [36]. We established xenograft tumors in mice by using H460 lung cancer cells transfected with GFP-expressing vectors encoding the wild-type or mutant derivatives of Bcl-w and p53. Expression of these exogenous genes did not significantly influence the size of xenograft tumors (Figure 8A). Tumor formation was followed by the appearance of the GFP-expressing tumor cells in mouse blood. The number of these circulating cells was increased by overexpression of Bcl-w, but not Bcl-w $\mathrm{w}^{\mathrm{G} 94 \mathrm{~A}}$ (Figure $8 \mathrm{~B}$ ), suggesting Bcl-w promotes the intravasation of tumor cells through binding to Bax. This intravasationpromoting ability of $\mathrm{Bcl}-\mathrm{w}$ was antagonized by expression of exogenous $\mathrm{p} 53$ or $\mathrm{p} 53^{\mathrm{K} 305 \mathrm{~N}}$, but not by $\mathrm{p} 53^{\mathrm{R} 175 \mathrm{H}}$ or $\mathrm{p} 53^{\mathrm{K} 305 \mathrm{~N} / \mathrm{R} 175 \mathrm{H}}$ (Figure $8 \mathrm{C}$ ), suggesting that nuclear and cytoplasmic p53 antagonize Bcl-w-induced tumor cell intravasation through transcriptional activity and Bcl-w binding, respectively. The properties of p53 and Bcl-w are similar to those determined in cell culture. Therefore, regulation of tumor cell invasion by the $\mathrm{p} 53 / \mathrm{Bcl}-\mathrm{w} / \mathrm{Bax}$ system appears to be applicable in vivo.

\section{DISCUSSION}

We have shown that p53 suppresses invasion not only by acting in the nucleus but also through its actions in the cytoplasm. Our data suggest this novel function
A

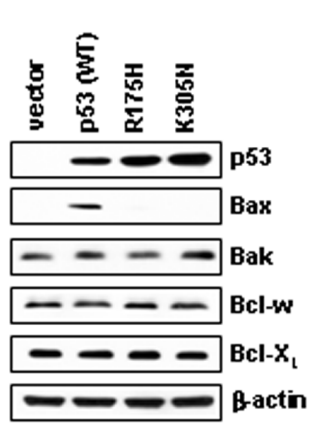

D

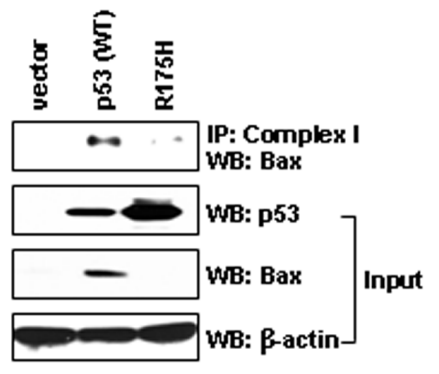

B

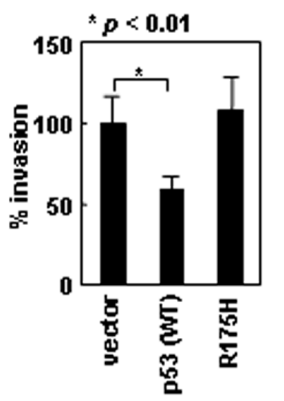

C

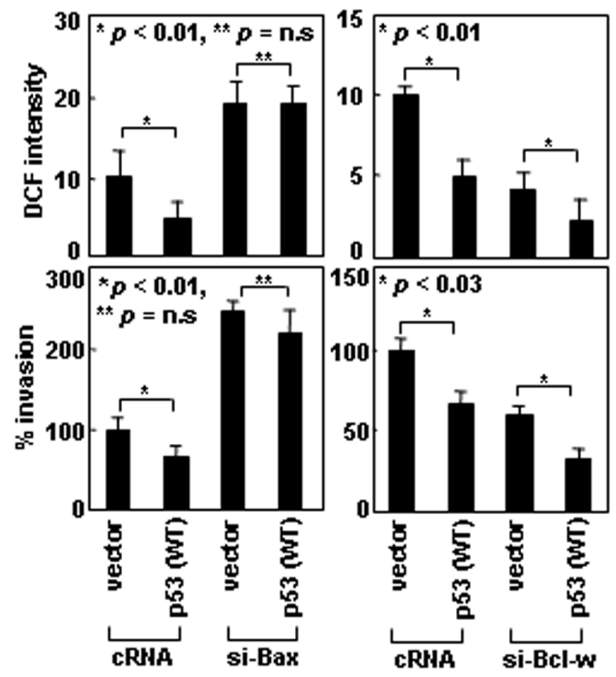

E

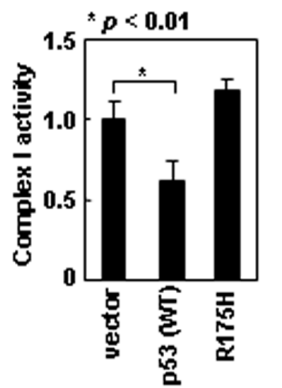

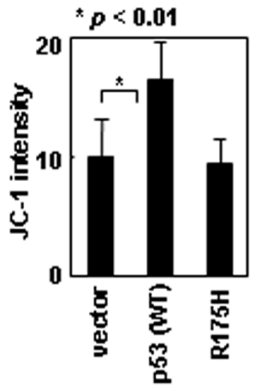

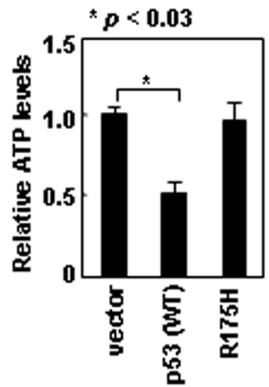

Figure 7: Nuclear p53 suppresses cell invasion by inducing Bax expression. (A) p53 wild-type or mutant derivatives were expressed in H1299 cells. Protein expression was assessed by Western blotting. (B) Invasion assays. (C) Cells transfected with siRNAs and expression vectors were analyzed for ROS and invasiveness. (D) Transfectants were lysed, immunoprecipitated, and analyzed by Western blotting. (E) Transfectants were analyzed for complex-I activity, $\Delta \Psi_{\mathrm{m}}$, and ATP. 
operates via the following mechanism: Cytoplasmic p53 binds to Bcl-w, which facilitates dissociation of Bax from Bcl-w. Bax then binds to complex-I and inhibits its activity. This results in a decrease in ROS production and invasiveness. However, when Bcl-w is up-regulated or the levels of cytoplasmic p53 are relatively low, Bcl-w/Bax interactions increase, promoting Bax release from complex-I. This leads to an increase in complex-I activity, and thus ROS production and invasiveness. Given that Bcl- $\mathrm{X}_{\mathrm{L}}$ and Bak can substitute for Bcl-w and Bax, respectively, in this system, cytoplasmic p53 appears to suppress complex-I activity by inhibiting the interactions between pro-survival and multidomain pro-apoptotic Bcl-2 proteins. We have further verified that nuclear p53 can also suppress complex-I activity by inducing

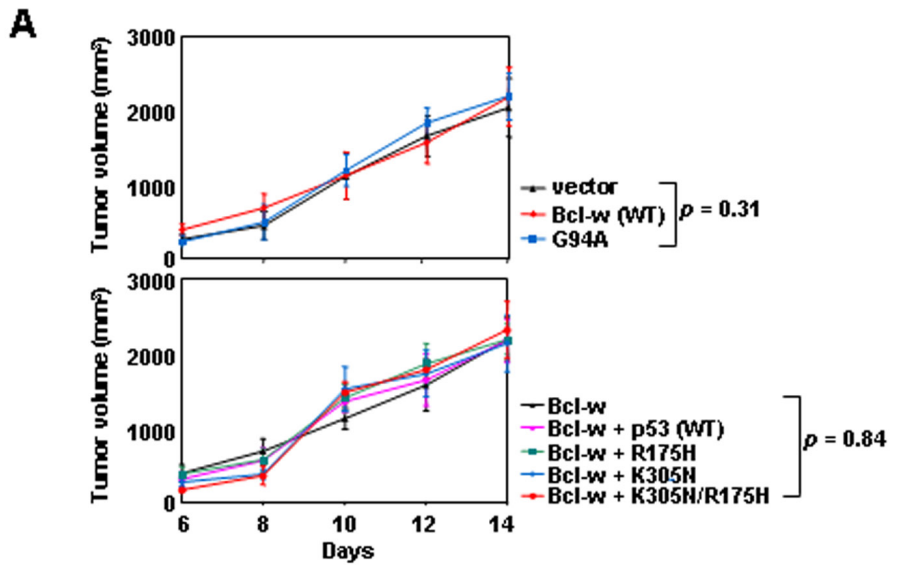

Bax expression. Collectively, our data suggest that p53 inhibits the mitochondrial pathway of cell invasion in a transcription-dependent and transcription-independent manner, summarized schematically in Figure 9A. Our findings are consistent with previous reports that although p53 promotes ROS production in apoptotic cells [37], it decreases ROS levels in healthy cells in association with decreased cellular energy metabolism and mTOR signaling or increased cellular antioxidant capacity [3840]. Importantly, our model may operate in vivo, as we have shown that p53 and $\mathrm{Bcl}-\mathrm{w}$ regulate the intravasation of cancer cells in an animal model. Given our findings, p53 appears to contribute to the suppression of tumor progression even through actions in the cytoplasm. Previous reports have also shown that cytoplasmic

B

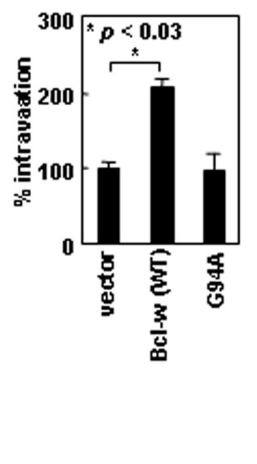

C

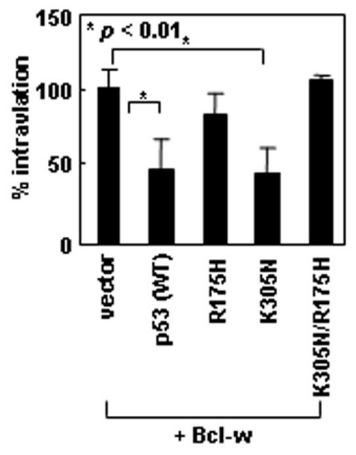

Figure 8: Cytoplasmic p53 and Bcl-w regulate cancer cell intravasation via mechanisms that depend on binding to Bcl-w and Bax, respectively. (A) H460 cells transfected with empty pEGFP-C1 vectors or the vectors encoding the indicated constructs were implanted to form xenograft tumors in mice. Tumor volumes were measured on the indicated days after implantation. After $\mathbf{2}$ weeks, mice were photographed and blood was obtained. (B and C) Blood cells were stained with DAPI and analyzed by confocal microscopy. Circulating tumor cells were identified as GFP- and DAPI-positive cells. Photographs of experimental mice and confocal images of analyzed cells are presented in Supplementary Figure S6.

A

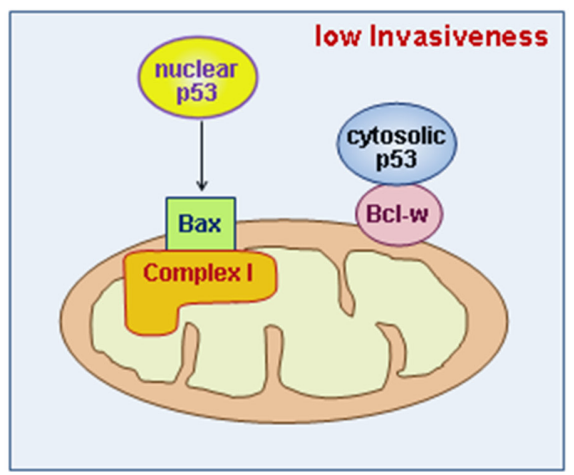

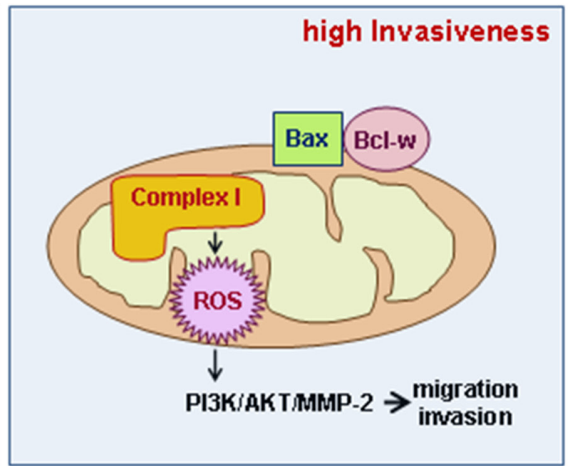

B

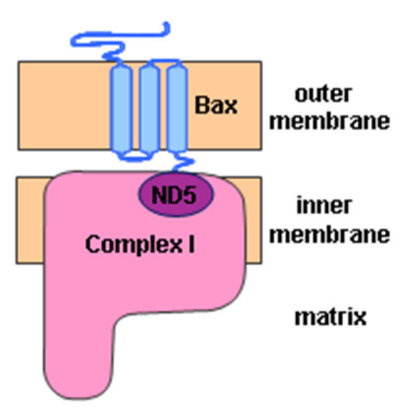

Figure 9: Schematic models. (A) Left: Cytoplasmic p53 binds Bcl-w, promoting release of Bax and allowing its interaction with complex-I. This inhibits complex-I activity and decreases ROS production and cellular invasiveness. Nuclear p53 also facilitates Bax/ complex-I interactions by promoting Bax expression. Right: Up-regulation of Bcl-w or down-regulation of p53 promotes Bcl-w/Bax interactions, releasing Bax from complex-I. This up-regulates complex-I activity and increases ROS production. ROS then stimulate the PI3K-dependent invasion pathway. (B) Interaction of Bax with complex-I. Bax resides in the outer mitochondrial membrane as a tailanchored form, protruding its C-terminal tail into the inter-membrane space. This topology may allow interaction of the tail with ND5 in the membrane arm of complex-I. 
accumulation of p53 supports the survival of endometrial carcinoma patients as much as its nuclear localization [41].

Another important finding is that complex-I is a major target of $\mathrm{Bcl}-2$ proteins in the regulation of mitochondrial metabolism and ROS production. Consistent with the pro-oxidant role of pro-survival Bcl2 members in healthy cells, Bcl-2 and Bcl- $\mathrm{X}_{\mathrm{L}}$ have been shown to increase mitochondrial respiration and ATP levels $[19,20]$. While the mechanisms underlying these phenomena have just begun to be studied, Bcl-2 has been proposed to bind complex-IV and enhance its activity [20]. In this study, we showed that Bcl-w also elevates $\Delta \Psi_{\mathrm{m}}$ and ATP levels; however, in contrast to Bcl-2, Bcl-w activated complex-I, but not complexes II-IV. While the reason for the difference between Bcl-2 and Bcl-w is not yet clear, the function of Bcl-w is consistent with the fact that complex-I is a major source of ROS in mitochondrial respiration [26]. However, in contrast to the effect of Bcl-w on complex-I activity, we found no evidence for effective binding of Bcl-w to complex I-IV, suggesting that Bcl-w activates complex-I indirectly. We indeed found that Bax directly binds to complex-I, inhibiting its activity, and that this function is prevented by Bcl-w. Considering that Bax and complex-I reside in the mitochondrial outer and inner membranes, respectively $[27,31]$, their interaction might be mediated by their sub-structures or subunits that protrude into or are exposed to the intermembrane space. This hypothesis is supported by the finding that Bax binds via its C-terminal tail to ND5 (Figure 9B). Considering our finding that Bak also binds to ND5 via its C-terminal tail, we propose that multidomain pro-apoptotic members are direct regulators of complex-I.

Interestingly, previous studies have shown that complex-I is frequently mutated in lung cancer patients: Nearly $40 \%$ of patients had mutations in the complex-I gene, and more than $80 \%$ of the complex-I mutations occurred in the ND5 gene [33]. This suggests mutations in complex-I, especially ND5, are critical to tumorigenesis or tumor progression, which was indeed supported by our finding that one such natural mutation in ND5 (ND5 ${ }^{\mathrm{G} 13289 \mathrm{~A}}$ ) promotes ROS production and cell invasion by preventing Bax/ND5 interactions. There results support the clinical relevance of Bax/ND5 interactions in cancer.

In summary, we have demonstrated the sequential interactions of cytoplasmic p53, Bcl-w, Bax and complex-I, which form a novel pathway that regulates ROS levels and invasiveness. These findings provide new insights into the regulation of cancer cell metastasis and metabolism.

\section{MATERIALS AND METHODS}

\section{Antibodies and inhibitors}

The following antibodies were used in this study: anti-p53 (Dako); anti-Bcl-w, anti-Bcl-X $\mathrm{L}_{\mathrm{L}}$, antiBax, anti-Bak, and anti-phospho-Akt (Cell Signaling Technology); anti-Akt, anti-ND2, anti-NDUFS1, and anti-NDUFV2 (Santa Cruz Biotechnology); anti-complex I, anti-complex II, anti-complex III, and anti-complex IV (Abcam); anti-MMP-2 (Calbiochem); anti-PI3K (Upstate Biotechnology); anti- $\beta$-actin (Sigma); anti-ND-1, and antiND5 (Novus Biologicals). Inhibitors of the mitochondrial respiratory chain were obtained from Sigma.

\section{SiRNAs}

All siRNAs were purchased from Ambion. When two sets of siRNAs were used, they were numbered siRNA-1 and -2. Their catalogue numbers are as follows: si-p53-1 (S605) and si-p53-2 (S606); si-Bax-1 (S1888) and si-Bax-2 (S1889); and si-Bak-1 (S1880) and si-Bak-2 (S1881). Where necessary, only the number 1 siRNAs were used and indicated without numbering, such as sip53, si-Bax, and si-Bak. The catalogue number of si-Bcl-w was S1924.

\section{Cell culture and transfection}

All cells were purchased from American Type Culture Collection, and were maintained in RPMI-1640 medium supplemented with 10\% FBS. Expression constructs and siRNAs were introduced with Lipofectamine 2000 (Invitrogen). After $24 \mathrm{~h}$ recovery, the transfectants were used for experiments, as indicated. In the case of pTRE-Tight vectors, the recovered transfectants were treated with tetracycline $(1 \mu \mathrm{g} / \mathrm{mL})$ for an additional $16 \mathrm{~h}$ to induce gene expression, and then used for the specified experiments. Where indicated, transfectants were selected by treatment with G418 sulfate $(0.5 \mathrm{mg} / \mathrm{mL})$.

\section{Western blot analysis}

Cell lysates and conditioned media were prepared using previously described methods [10]. Proteins in samples were separated by SDS-PAGE, electrotransferred to Immobilon membranes (Millipore, Bedford, MA), and analyzed using the specified antibodies and an ECL detection system (Amersham). 


\section{Invasion assay}

Cells were seeded onto the upper surfaces of Matrigel-coated polycarbonate filters (BD Biosciences) in a modified Boyden chamber (Corning), and analyzed for their invasiveness as described previously [8].

\section{Analysis of mitochondrial complex activities}

Complex I, II, and IV activities were analyzed using the respective Microplate Assay kit (MitoSciences). Complex III activity was analyzed by incubating mitochondria $(0.5 \mathrm{mg}$ protein per $\mathrm{ml})$, prepared using a previously described method [10] in a potassium phosphate buffer ( $25 \mathrm{mM}, \mathrm{pH} 7.2)$ containing $2 \mathrm{mM} \mathrm{KCN}$ and $40 \mu \mathrm{M}$ reduced decylubiquinone. The reaction was initiated by adding $50 \mu \mathrm{M}$ cytochrome c; reduction was measured by spectrophotometry at $550 \mathrm{~nm}$.

\section{Measurement of cellular ATP levels}

This assay was conducted by analyzing cell lysates using the ATP Bioluminescent Somatic Cell Assay Kit (Sigma-Aldrich) according to the manufacturer's instruction.

\section{Analysis of ROS levels}

Cells were exposed to either $10 \mu \mathrm{M}$ 2'7'-dichlorodihydrofluorescein diacetate (DCF-DA; Molecular Probes) or $10 \mu \mathrm{M}$ MitoSOX Red (Invitrogen) for $30 \mathrm{~min}$. Cell-associated levels of fluorescence were analyzed by flow cytometry.

\section{$\Delta \Psi \mathrm{m}$ analysis}

Cells were incubated with $10 \mu \mathrm{g} / \mathrm{ml} \mathrm{JC}-1$ (SigmaAldrich) for $30 \mathrm{~min}$, and subsequently analyzed by flow cytometry. An increase in $\Delta \Psi_{\mathrm{m}}$ was monitored as a decrease in JC-1 monomers (FL-1 channel) [42].

\section{Co-immunoprecipitation assay}

Cells were lysed in buffer containing $25 \mathrm{mM}$ Tris$\mathrm{HCl}$ (pH 7.4), $120 \mathrm{mM} \mathrm{NaCl}, 0.5 \% \mathrm{NP}-40,4 \mathrm{mM} \mathrm{NaF}$, $100 \mu \mathrm{M} \mathrm{Na}_{3} \mathrm{VO}_{4}$. Equal amounts of proteins $(300 \mu \mathrm{g})$ were incubated overnight with the indicated antibodies at $4^{\circ} \mathrm{C}$, followed by the addition of protein G-Sepharose beads (Amersham), and an additional $3 \mathrm{~h}$ incubation. The precipitates were washed three times with lysis buffer, and the proteins were analyzed by Western blotting.

\section{In vitro binding assay}

Genes were cloned into pcDNA vectors and translated in vitro using TNT Quick Coupled Transcription/Translation Systems (Promega) according to manufacturer' protocols. Protein binding was analyzed by co-immunoprecipitation. Where indicated, the expressed proteins were incubated with GST or GSTcoupled proteins (Abnova), followed by precipitation with glutathione-conjugated Sepharose (Amersham). The precipitates were analyzed by Western blotting.

\section{Expression constructs and mutagenesis}

Expression constructs were prepared using pcDNA3, $\mathrm{pCMV} / \mathrm{myc} / \mathrm{mito}$, pEGFP-C1, and pTRE-Tight vectors. The former two vectors were obtained from Invitrogen, while the latter was from Clontech. These vectors were used for the following purposes: pEGFP-C1, for confocal microscopy and intravasation assays; pTRE-Tight, for the expression of pro-apoptotic Bcl-2 members (Bax and Bak); pCMV/myc/mito, for the expression of ND5 and ND5 ${ }^{\mathrm{G} 13289 \mathrm{~A}}$; and pcDNA3, for all other purposes. p53 $3^{\mathrm{R} 175 \mathrm{H}}$, $\mathrm{p} 53^{\mathrm{K} 305 \mathrm{~N}}, \mathrm{p} 53^{\mathrm{K} 305 \mathrm{~N} / \mathrm{R} 175 \mathrm{H}}, \mathrm{Bcl}-\mathrm{w}^{\mathrm{G} 94 \mathrm{~A}}$, and $\mathrm{ND}^{\mathrm{G} 13289 \mathrm{~A}}$ were prepared using the QuikChange Site-Directed Mutagenesis Kit (Stratagene) [43].

\section{Animals}

Female BALB/cAnNCrj-nu/nu mice (6 wks old) were purchased from Charles River. All animal experiments were performed under approved protocols of our Institutional Animal Care and Use Committee.

\section{Intravasation assay}

H460 cells stably transfected with pEGFP-C1 vectors encoding the indicated genes were subcutaneously injected into the hind legs of mice $\left(10^{7} /\right.$ mouse) to form xenograft tumors. Tumor volumes were calculated as described [44]. After 2 weeks, mice were anesthetized, blood was obtained via cardiac puncture, and $0.1 \mathrm{~mL}$ of blood was mixed with $2 \mathrm{~mL}$ RBC-lysis buffer (Intron Biotech). Cells were collected by centrifugation ( $350 \mathrm{~g}$, 5 min), resuspended in PBS, stained with DAPI, and then analyzed by confocal microscopy. Circulating tumor cells were identified as GFP- and DAPI-positive cells.

\section{Statistical analysis}

Experiments were performed three times and data are reported as means and standard deviations. Statistical significance was defined as $P<0.05$, which was 
determined by a Student's $t$ test or one-way ANOVA using GraphPad software.

\section{CONFLICT OF INTEREST}

The authors declare no conflict of interest.

\section{ACKNOWLEDGEMENTS}

This work was supported by the National Research Foundation of Korea (NRF) grant funded by the Korean government (MSIP) (2012M2A2A7010459, 2012R1A2A2A01045978, 2008-0062611).

\section{REFERENCES}

1. Muller PA, Vousden KH, Norman JC. p53 and its mutants in tumor cell migration and invasion. J Cell Biol. 2011; 192: 209-218

2. Riley T, Sontag E, Chen P, Levine A. Transcriptional control of human p53- regulated genes. Nat Rev Mol Cell Biol. 2008; 9: 402-412.

3. Moll UM, LaQuaglia M, Bénard J, Riou G. Wild-type p53 protein undergoes cytoplasmic sequestration in undifferentiated neuroblastomas but not in differentiated tumors. Proc Natl Acad Sci USA. 1995; 92: 4407-4411.

4. Jansson A, Gentile M, Sun XF. p53 Mutations are present in colorectal cancer with cytoplasmic p53 accumulation. Int J Cancer. 2001; 92: 338-341.

5. Sembritzki O, Hagel C, Lamszus K, Deppert W, Bohn W. Cytoplasmic localization of wild-type p53 in glioblastomas correlates with expression of vimentin and glial fibrillary acidic protein. Neuro Oncol. 2002; 4: 171-178.

6. Moll UM, Riou G, Levine AJ. Two distinct mechanisms alter p53 in breast cancer: mutation and nuclear exclusion. Proc Natl Acad Sci USA. 1992; 89: 7262-7266.

7. Cory S, Adams JM. The Bcl2 family: regulators of the cellular life-or-death switch. Nat Rev Cancer. 2002; 2: 647656.

8. Bae IH, Park MJ, Yoon SH, Kang SW, Lee SS, Choi KM, Um HD. Bcl-w promotes gastric cancer cell invasion by inducing matrix metalloproteinase-2 expression via phosphoinositide 3-kinase, Akt, and Sp1. Cancer Res. 2006; 66: 4991-4995.

9. Bae IH, Yoon SH, Lee SB, Park JK, Ho JN, Um HD. Signaling components involved in Bcl-w-induced migration of gastric cancer cells. Cancer Lett. 2009; 277: 22-28.

10. Kim EM, Kim J, Park JK, Hwang SG, Kim WJ, Lee WJ, Kang SW, Um HD. Bcl-w promotes cell invasion by blocking the invasion-suppressing action of Bax. Cell Signal. 2012; 24: 1163-1172.

11. Weiler M, Bähr O, Hohlweg U, Naumann U, Rieger J, Huang H, Tabatabai G, Krell HW, Ohgaki H, Weller M,
Wick W. BCL-xL: time-dependent dissociation between modulation of apoptosis and invasiveness in human malignant glioma cells. Cell Death Differ. 2006; 13: 11561169.

12. Ho JN, Kang GY, Lee SS, Kim J, Bae IH, Hwang SG, Um HD. Bcl-XL and STAT3 mediate malignant actions of gamma-irradiation in lung cancer cells. Cancer Sci. 2010; 101: 1417-1423.

13. Choi J, Choi K, Benveniste EN, Rho SB, Hong YS, Lee JH, Kim J, Park K. Bcl-2 promotes invasion and lung metastasis by inducing matrix metalloproteinase-2. Cancer Res. 2005; 65: 5554-5560.

14. Zuo J, Ishikawa T, Boutros S, Xiao Z, Humtsoe JO, Kramer RH. Bcl-2 overexpression induces a partial epithelial to mesenchymal transition and promotes squamous carcinoma cell invasion and metastasis. Cancer Res. 2010; 8: 170-182.

15. Del Bufalo D, Biroccio A, Leonetti C, Zupi G. Bcl-2 overexpression enhances the metastatic potential of a human breast cancer line. FASEB J. 1997; 11: 947-953.

16. Du YC, Lewis BC, Hanahan D, Varmus H. Assessing tumor progression factors by somatic gene transfer into a mouse model: Bcl-xL promotes islet tumor cell invasion. PLoS Biol. 2007; 5: 2255-2269.

17. Lee HW, Lee SS, Lee SJ, Um HD. Bcl-w is expressed in a majority of infiltrative gastric adenocarcinomas and suppresses the cancer cell death by blocking stress-activated protein kinase/c-Jun NH2-terminal kinase activation. Cancer Res. 2003; 63: 1093-1100.

18. Watanabe J, Kushihata F, Honda K, Sugita A, Tateishi N, Mominoki K, Matsuda S, Kobayashi N. Prognostic significance of Bcl-xL in human hepatocellular carcinoma. Surgery. 2004; 135: 604-612.

19. Manfredi G, Kwong JQ, Oca-Cossio JA, Woischnik M, Gajewski CD, Martushova K, D’Aurelio M, Friedlich AL, Moraes CT. BCL-2 improves oxidative phosphorylation and modulates adenine nucleotide translocation in mitochondria of cells harboring mutant mtDNA. J Biol Chem. 2003; 278: 5639-5645.

20. Chen ZX, Pervaiz S. Involvement of cytochrome c oxidase subunits $\mathrm{Va}$ and $\mathrm{Vb}$ in the regulation of cancer cell metabolism by Bcl-2. Cell Death Differ. 2010; 17: 408-420.

21. Vaseva AV, Moll UM. The mitochondrial p53 pathway. Biochim Biophys Acta. 2009; 1787: 414-420.

22. Liang SH, Hong D, Clarke MF. Cooperation of a single lysine mutation and a C-terminal domain in the cytoplasmic sequestration of the p53 protein. J Biol Chem. 1998; 273: 19817-1921.

23. Ajay AK, Upadhyay AK, Singh S, Vijayakumar MV, Kumari R, Pandey V, Boppana R, Bhat MK. Cdk5 phosphorylates non-genotoxically overexpressed p53 following inhibition of PP2A to induce cell cycle arrest/ apoptosis and inhibits tumor progression. Mol Cancer. 2010; 9: 204-218.

24. Tomita Y, Marchenko N, Erster S, Nemajerova A, Dehner 
A, Klein C, Pan H, Kessler H, Pancoska P, Moll UM. WT p53, but not tumor-derived mutants, bind to $\mathrm{Bcl} 2$ via the DNA binding domain and induce mitochondrial permeabilization. J Biol Chem. 2006; 281: 8600-8606.

25. Kim EM, Yang HS, Kang SW, Ho JN, Lee SB, Um HD. Amplification of the gamma-irradiation-induced cell death pathway by reactive oxygen species in human U937 cells. Cell Signal. 2008; 20: 916-924.

26. Murphy MP. How mitochondria produce reactive oxygen species. Biochem J. 2009; 417: 1-13.

27. Annis MG, Soucie EL, Dlugosz PJ, Cruz-Aguado JA, Penn LZ, Leber B, Andrews DW. Bax forms multispanning monomers that oligomerize to permeabilize membranes during apoptosis. EMBO J. 2005; 24: 2096-2103.

28. Ferrer PE, Frederick P, Gulbis JM, Dewson G, Kluck RM. Translocation of a Bak C-terminus mutant from cytosol to mitochondria to mediate cytochrome $\mathrm{C}$ release: implications for Bak and Bax apoptotic function. PLoS One. 2012; 7: e31510.

29. Green DR, Walczak H. Apoptosis therapy: driving cancers down the road to ruin. Nat Med. 2013; 19: 131-133.

30. Schellenberg B, Wang P, Keeble JA, Rodriguez-Enriquez R, Walker S, Owens TW, Foster F, Tanianis-Hughes J, Brennan K, Streuli CH, Gilmore AP. Bax exists in a dynamic equilibrium between the cytosol and mitochondria to control apoptotic priming. Mol Cell. 2013; 49: 959-971.

31. Vogel RO, Smeitink JA, Nijtmans LG. Human mitochondrial complex I assembly: a dynamic and versatile process. Biochim Biophys Acta. 2007; 1767: 1215-1227.

32. Gillissen B, Wendt J, Richter A, Richter A, Müer A, Overkamp T, Gebhardt N, Preissner R, Belka C, Dörken B, Daniel PT. Endogenous Bak inhibitors Mcl-1 and Bcl-xL: differential impact on TRAIL resistance in Bax-deficient carcinoma. J Cell Biol. 2010; 188: 851-862.

33. Dasgupta S, Soudry E, Mukhopadhyay N, Shao C, Yee J, Lam S, Lam W, Zhang W, Gazdar AF, Fisher PB, Sidransky D. Mitochondrial DNA mutations in respiratory complex-I in never-smoker lung cancer patients contribute to lung cancer progression and associated with EGFR gene mutation. J Cell Physiol. 2012; 227: 2451-2460.

34. Sengupta S, Vonesch JL, Waltzinger C, Zheng H, Wasylyk B. Negative cross-talk between p53 and the glucocorticoid receptor and its role in neuroblastoma cells. EMBO J. 2000; 19: 6051-6064.

35. Farmer G, Friedlander P, Colgan J, Manley JL, Prives C. Transcriptional repression by p53 involves molecular interactions distinct from those with the TATA box binding protein. Nucleic Acids Res. 1996; 24: 4281-4288.

36. Stacker SA, Williams SP, Karnezis T, Shayan R, Fox SB, Achen MG. Lymphangiogenesis and lymphatic vessel remodelling in cancer. Nat Rev Cancer. 2014; 14: 159-172.

37. Vousden KH, Ryan KM. p53 and metabolism. Nat Rev Cancer. 2009; 9: 691-700.

38. Samper E, Morgado L, Estrada JC, Bernad A, Hubbard A,
Cadenas S, Melov S. Increase in mitochondrial biogenesis, oxidative stress, and glycolysis in murine lymphomas. Free Radic Biol Med. 2009; 46: 387-396.

39. Demidenko ZN, Korotchkina LG, Gudkov AV, Blagosklonny MV. Paradoxical suppression of cellular senescence by p53. Proc Natl Acad Sci U S A. 2010; 107: 9660-9664.

40. Maddocks OD, Vousden KH. Metabolic regulation by $\mathrm{p} 53$. J Mol Med (Berl). 2011; 89: 237-245.

41. Soong R, Knowles S, Williams KE, Hammond IG, Wysocki $\mathrm{SJ}$, Iacopetta BJ. Overexpression of p53 protein is an independent prognostic indicator in human endometrial carcinoma. Br J Cancer. 1996; 74: 562-567.

42. Stridh H, Kimland M, Jones DP, Orrenius S, Hampton MB. Cytochrome c release and caspase activation in hydrogen peroxide- and tributyltin-induced apoptosis. FEBS Lett. 1998; 429: 351-355.

43. Short KM, Cox TC. Subclassification of the RBCC/TRIM superfamily reveals a novel motif necessary for microtubule binding. J Biol Chem. 2006; 281: 8970-8980.

44. Jackson T, Chougule MB, Ichite N, Patlolla RR, Singh M. Antitumor activity of noscapine in human non-small cell lung cancer xenograft model. Cancer Chemother Pharmacol. 2008; 63: 117-126. 